\title{
EDITORIAL
}

\section{A abolição não realizada: sou negro(a) na pele, na alma, na voz e na luta}

No dia 13 de maio comemora-se a abolição da escravatura. Naquele dia, em 1888... homens e mulheres escravizados aguardavam com grande expectativa a aprovação do projeto de lei, que trazia em seu primeiro artigo a extinção da escravidão no Brasil. Relatos daquela ocasião enfatizam aglomerações nas ruas das principais cidades e regiões, a espera de algo que mudaria a vida de muitas pessoas...

013 de maio foi fruto de importantes atores sociais envolvidos no amplo movimento social, que se efetivou nos espaços públicos, em instituições, na clandestinidade. A dizer também que a escravidão no país passou a ser contestada pela Inglaterra, interessada em ampliar seu mercado consumidor com o Brasil. A Lei Áurea, portanto, estava longe de ser um ato de vontade da Coroa, não significando a emancipação efetiva da população escravizada.

Atualmente, também se comemora esta data... mas como um dia de luta, pois a abolição não foi realizada. Constituiu-se de manobras sociais e políticas. A pretensão aqui é enfatizar que 13 de maio é mais um dia de luta como todos os outros dias, aos negros e negras.

É dia de homenagear tantos e tantas que resistem ao racismo e discriminação no país. É dia de falar de Carolina de Jesus, escritora mineira, que viveu boa parte de sua vida na favela como catadora de papéis, superou o analfabetismo e com paixão pelas letras e sensibilidade escreveu, entre outras obras, "Quarto de Despejo".

Nesta obra, ela representa a voz dos excluídos; um diário autobiográfico, composto de críticas e denúncias sobre as condições de uma favela. Registra de forma simples e verdadeira fatos relevantes da vida política e social do Brasil de 1955 a 1960.

Os textos que compõem sua obra foram produzidos sob o governo de Juscelino Kubitschek, em que o país se desenvolvia em infraestrutura, ao mesmo tempo que pessoas marginalizadas se aglutinavam em favelas sob condições miseráveis.

É dia também de apresentar Tula Pilar, poetisa, moradora de Taboão da Serra, que traz em seus trabalhos os abusos vividos em sua trajetória de vida, como mulher negra, empregada doméstica, babá, cozinheira.

A artista ganhou reconhecimento por participar e organizar saraus na periferia de São Paulo. Trabalhava de forma independente com sua poesia que expressa o combate às opressões. Entre seus trabalhos, destacam-se: "Palavras Inacadêmicas" e "Sensualidade de Fino Trato".

Tula Pilar tem interesse pelo conhecimento e resgate da cultura africana. Enfatiza a relevância de conhecer a verdadeira história para não fortalecer um sistema de desigualdade e alienação.

Assim, como tantas outras que permanecem resistindo diariamente contra as opressões, racismo, exploração humana, escravidão.... é dia de refletir sobre "a abolição não realizada".

Boa Leitura!

Marta Regina Farinelli

Assistente Social. Bacharel em Direito. Mestre e Doutora em Serviço Social. Professora Associada do Curso de Serviço Social, do Programa de Pós Graduação em Psicologia e, do Programa de Residência Integrada e Multiprofissional em Saúde da Universidade Federal do Triângulo Mineiro. 